\title{
The Dilemma of Agricultural Mechanization and the Marginalization of Women Farmworkers in Rural Areas
}

\section{Dilema Mekanisasi Pertanian dan Marginalisasi Buruh Tani Perempuan di Pedesaan}

\author{
Fuat Edi Kurniawan*
}

Research Center for Population, Indonesian Institute of Sciences (LIPI), Jakarta

${ }^{*}$ E-mail: edy.fuad@gmail.com

Received: September 20, 2020 | Revised: May 29, 2021 | Accepted: July 1, 2021 | Online publication: August 18, 2021

\begin{abstract}
Agricultural mechanization is one of the efforts to accelerate agricultural development through technological changes in agriculture. However, mechanization replaced human labor. The development of agricultural equipment and machinery technology $(=$ Alsintan), which produces agricultural processing machines, has created a new role that replaces agricultural laborers' position. Women farmworkers are the most disadvantaged by mechanization. This study used a qualitative research method with a case study in Gadingsari Village, Bantul. This study shows that agricultural mechanization in Gadingsari Village has shifted the working mechanism of agriculture, to cultivate rice fields from human power to Alsintan, such as tractors, grinding machines, and threshing machines. Apart from leaving the traditional agricultural processing system, this change directly affects female agricultural laborers' employment opportunities because machinery has replaced the job and because men operate the majority of Alsintan. Hence, the dilemma: Changes in agricultural technology accelerate agricultural development, but at the same time increasingly marginalize female agricultural laborers. In the concept of a risk society, gender-biased technology places women at risk of modernity. Consequently, reflection on these risks is needed to find ways to accelerate inclusive agricultural development and promote gender equality.
\end{abstract}

Keywords: agricultural mechanization, farmworker, inclusive agricultural development, marginalization of women

\section{ABSTRAK}

Mekanisasi pertanian pada dasarnya merupakan usaha percepatan pembangunan pertanian melalui perubahan teknologi di sektor pertanian. Namun mekanisasi justru menggusur tenaga kerja manusia. Perkembangan teknologi alat dan mesin pertanian (Alsintan) yang menciptakan mesin-mesin pengolah pertanian menjadikan peran baru yang menggantikan posisi buruh tani. Buruh tani perempuan merupakan pihak yang paling dirugikan dengan adanya mekanisasi pertanian ini. Studi ini menggunakan metode penelitian kualitatif dengan pendekatan studi kasus di Desa Gadingsari Bantul. Hasil dari penelitian ini menunjukkan bahwa mekanisasi pertanian di Desa Gadingsari telah menggeser mekanisme kerja pertanian dari tenaga manusia untuk mengolah sawah menjadi Alsintan, seperti traktor, mesin penggiling, dan mesin perontok. Selain meninggalkan sistem pengolahan pertanian tradisional, perubahan ini secara langsung berdampak pada peluang kerja buruh tani perempuan karena mesin telah menggantikan pekerjaan dan mayoritas Alsintan dioperasikan oleh laki-laki. Perubahan teknologi pertanian menjadikan posisi buruh tani perempuan semakin termarginalkan. Usaha mekanisasi pertanian menjadi dilematis karena perubahan teknologi di pertanian dipahami menjadi sebuah keniscayaan yang dapat meningkatkan percepatan pembangunan pertanian, tetapi pada saat yang sama semakin meminggirkan perempuan buruh tani. Dalam konsep masyarakat risiko, teknologi bias gender menempatkan perempuan pada risiko modernitas. Konsekuensinya, refleksi atas risiko-risiko ini diperlukan untuk menemukan cara mempercepat pembangunan pertanian yang inklusif dan mengedepankan kesetaraan gender.

Kata kunci: mekanisasi pertanian, buruh tani, pembangunan pertanian inklusif, marginalisasi perempuan

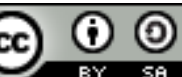

Content from this work may be used under the terms of the Creative Commons Attribution-ShareAlike

4.0 International. Any further distribution of this work must maintain attribution to the author(s) and the title of the work, journal citation and DOI.

Published under Department of Communication and Community Development Science, IPB University and in association with Ikatan Sosiologi Indonesia

E-ISSN: 2302-7525 | P-ISSN: 2302-7157 


\section{INTRODUCTION}

Rural development has resulted in various changes, especially in the community's economic and cultural structure, especially farmers and farm laborers. The modernization paradigm in agricultural development that prioritizes the principle of efficiency impacts changes in farmer households' economic structure. Agricultural development in rural areas has led to rapid economic growth, although such growth is not reflected in farm households' income structure. Due to the relatively faster shift in the sectoral economy's pace, it impacts Indonesia's turning point in economic activities with a surplus of labor. (Manning 2000).

The modernization Paradigm in agricultural sector is an attempt to accelerate agricultural development through technological changes, i.e., mechanization. Technological changes occur in rice farming, which is the staple crop required by most Indonesians. These agricultural technologies have resulted in changes including the use of tractors for land preparation, improved (high yield) seeds, chemical fertilizers and pesticides, methods of harvesting, and post-harvest technology (Mahanani 2003).

In his classic 1973 work entitled "Modernization without Development in Rural Java," Sajogyo reflected the impact of the Green Revolution and pointed out that the Green Revolution only benefited the upper-class peasants and accelerated the smallholders' proletarization. This work was one of the primary references in the Green Revolution study, which took place in various continents, which is associated with rural social differentiation (Sajogyo 1973). Furthermore, Sajogyo also subtly but firmly proposed again the government's need to provide agricultural laborers in villages with access to land through a cooperative land provision program. He wrote, "... If the government has a far-sighted policy, the potential of the many farm laborers (heads of families) in Java can be mobilized. How? With land reform!" (Geertz 1983).

However, agricultural mechanization, which impacts the massive use of agricultural tools and machinery (Alsintan), shifts human power. The phenomenon of using a tractor is an example. The use of tractors will reduce the number of home workers. Agriculture must be made into a labor-intensive sector. However, with the mechanization of agriculture, modernity conditions have increasingly shifted the unreliable pattern of human labor in agriculture. For the first time, those who lost their jobs were women agricultural labors because women were positioned to do manual labor in agriculture (Boserup 1984). This condition quickly puts pressure on women farm labors and significantly increases the number of unemployed women farm labors (Rola-Rubzen et al. 2020).

The problem of Indonesian agricultural workers during the mechanization of agriculture is complex. On the one hand, the need for and consumption of food increases, and on the other hand, agricultural laborers cannot take advantage of increasing availability of food. Meanwhile, Indonesia's agricultural sector is one of the main sectors in Indonesia's economic activities because more than $50 \%$ of the population depends on the agricultural sector for their livelihoods. Most of the 23 million head farmers are women, wives, or mothers involved in the agricultural sector (Priminingtyas 2013). Based on BPS data (2013), there were around 237 million people, 36.5 percent of the total population, depending on their livelihoods in the agricultural sector, both as farmers and agricultural laborers. Residents in rural areas who work as agricultural laborers come from the poor families.

The problem for agricultural laborers is how their position in this sector can survive. Their life has been made more difficult since technological developments changed the agricultural system. Various consequences have started to emerge, one of which is a change in the labor system and reduced access to women who work in the agricultural sector. In the past, women had a significant role in the world of agriculture (Cele et al. 2020). The economic contribution given to household welfare comes from the disbursement of jobs in the agricultural sector. However, due to system changes affecting the workforce, women have become marginalized.

The development of machine-creating technology has become a new role that replaces the farm laborer, mostly women. As stated by Duran and Standing (Suratiyah et al. 1991), the higher the level of economic and technological development in agriculture, the lower the level of women's participation. Female workers tend to be underdeveloped due to being pushed out of the labor market, especially in the agricultural sector due to technological changes prioritizing men. This is supported by the industrial world's development, which is increasingly developing and affecting rural agriculture due to the Green Revolution (Kodiran and Hudayana 1990). 
Women agricultural workers are the most disadvantaged by the mechanization of agriculture. Mechanization has changed the method of weeding, harvesting rice to final processing into rice, all of which have eliminated women farmers from the agricultural production process. In several studies in Java and Bali, it has been known that due to rice processing machines or hullers, a total of 3,071 women workers in Cianjur (West Java), 3,229 people in Polanharjo District (Central Java), and 482 women workers in Bolung District, and 84 people in Tabanan (Bali) sub-district lost their livelihoods as rice pounder laborers. The rice pounder must change the type of work into odd jobs at lesser wages. Already, the wages of women agricultural laborers are differentiated from those of male agricultural laborers due to perception that women's work require less strength and of lower skill compared to men. The demand for changes to the agricultural production model reinforces women farmers' exclusion from the agricultural sector (Mahanani 2003).

In the Special Region of Yogyakarta (DIY), the female population is 1,748,581, or 54\% of the total population. Of those, the number of women who work as agricultural laborers is 473,839 , or more than a quarter. The women laborers make a living in the agricultural sector. Women farmworkers in rural Bantul, Yogyakarta, are increasingly displaced due to agricultural mechanization. At any current harvest season, they have less opportunity, compared to men, to be involved in the harvest process. The work carried out by some women farmworkers is only scavenging for fallen rice (ngangsak) the leftovers rice seeds found in the fields. The women farmworker collects the loose rice bit by bit and then brings it home to be consumed.

The potential of women in agricultural development and food security is very strategic. They are involved in heavy agriculture, such as cultivating rice fields, and light ones such as processing agricultural products. However, women's role in the agricultural sector is often marginalized due to the patriarchal culture in society. The patriarchal culture led to a gendered division of labor in agriculture (Research Institute (IFPRI) 2019). Some jobs are done by only women or men, others are open to both men and women. The development of agricultural mechanization is less gender oriented. The creation of Alsintan innovation does not only require less labor but also is to be operated by men. It draws the author's attention in this article, which is to provide a critical review of agricultural mechanization policy with an emphasis on the position of women farmworkers who are increasingly marginalized from the business.

\section{METHOD}

This study used a qualitative research method with a case study approach. A case study approach in done by exploring a particular phenomenon (case) in a time and activity (program, event, process, institution, or social group) and collecting detailed and in-depth information using various data collection procedures over a certain period (Creswell 2013). A case study's focus is the specification of a case in an event, whether it includes an individual, cultural group, or a portrait of life.

Furthermore, John W. Creswell stated several characteristics of a case study, namely: (1) Cases for a study are identified; (2) The case is a system bound by time and place; (3) Case studies use various sources of information in data collection to provide a detailed and in-depth description of the response to an event, and (4) Using this case study approach, researchers describe the context or setting for a case (Creswell 2013). In this study, the leading case is the agricultural community in rural Bantul, an agricultural community with many farm laborers that belong to the lower-middle-class economy.

Meanwhile, Robert K. Yin divided general case study research into 2 (two) types: case study research using single and multiple cases. Also, he classifies them based on the number of analysis units, namely, holistic case study research using one unit of analysis and embedded case study research, which uses several or many units of analysis. Case study research is called embedded because it is tied to its predetermined units of analysis. The analysis unit itself is needed to focus more research on its aims and objectives. Determination of the unit of analysis is determined through theoretical studies. Meanwhile, in holistic case study research, research is carried out more freely and focused on the studied case. It is not tied to the analysis unit because it is integrated into the case itself (Yin 2009).

Guided by the type of research that has been described above, this research uses a type of embedded case study research with a single-case design type. In this case, the researcher examines how the agricultural mechanization process shifts women agricultural laborer to gain access to jobs in on-farm 
agriculture. Women farm labors must have other strategies in getting income to meet their household needs. The research location is in Gadingsari Village, Sanden District, Bantul Regency. Gadingsari Village consists of 20 hamlets, which are areas with large and potential agricultural land. This research's location was chosen because most of the people in Gadingsari Village were agricultural laborers, and most of them belonged to the middle to low-income households. This research activity was carried out in the period from August to November 2017.

The technique of analyzing the data used in this research is to collect data from field findings after conducting in-depth interviews with women farmworkers in Gadingsari Village related to the ongoing agricultural mechanization process and to the way they get access to agriculture works in Gadingsari Village. Secondary data are related to agricultural data from BPS D.I Yogyakarta, monograph data from Gadingsari Village, and literature studies concerning shifts in agricultural economic activities.

From the interviews with informants, data from BPS, and monograph data of Gadingsari Village, the researchers then selected these data (coding data) based on the research needs. Furthermore, the data obtained were sorted by the existing problem formulations and abstracts, and interpreted according to research needs. Primary and secondary data that have been selected in advance are adjusted to the needs of research related to the above problems and then analyzed using the Risk Society Theory from Ulrich Beck.

\section{RESULTS AND DISCUSSION}

\section{Women and Demographic Conditions in Gadingsari Village, Bantul}

Most of the residents of Gadingsari Village work and earn a living in the agricultural sector. It is understandable because the agricultural sector is the sector that opens the most opportunities for rural areas. Working in agriculture does not require high education because physical labor is needed to work on agricultural land. Therefore, agriculture is still the dominant sector in rural areas, especially in Gadingsari Village. It can be seen from the following table:

Table 1. The population of Gadingsari Village by Workforce and Type of Work

\begin{tabular}{lrrr}
\hline \multicolumn{1}{c}{ Workforce } & \\
\hline \multicolumn{1}{c}{ Type of work } & Number of Men & $\begin{array}{c}\text { Number of } \\
\text { Women }\end{array}$ & Total \\
\hline Laborers in Agricultural Sector & 1,320 & 1,323 & 2,643 \\
Unemployment & 649 & 629 & 1,278 \\
Entrepreneur & 617 & 617 & 1,234 \\
Non-Agricultural Laborers & 554 & 522 & 1,076 \\
Private Companies Workers & 371 & 351 & 722 \\
Other jobs & 190 & 207 & 397 \\
Government Employees & 173 & 178 & 351 \\
Homeworkers & 0 & 334 & 334 \\
Police & 16 & 1 & 17 \\
Indonesian National Army & 16 & 0 & 16 \\
Medical Personnel & 3 & 3 & 14 \\
State Owned Enterprise Employees & 8 & 0 & 11 \\
State Officials & 1 & 4,176 & 1 \\
Total Workforce & 3,918 & & 8,094 \\
\hline Percentage of the Workforce & & $\mathbf{7 9 . 2 3 \%}$ \\
\hline
\end{tabular}




\begin{tabular}{lrrr}
\hline \multicolumn{1}{c}{ Non-Workforce } \\
\hline \multicolumn{1}{c}{ Activity } & Number of Men & $\begin{array}{c}\text { Number of } \\
\text { Women }\end{array}$ & Total \\
\hline Student / Student & 934 & 960 & 1894 \\
Retired \& Elderly & 155 & 73 & 228 \\
Total Non-Workforce & 1,089 & 1,033 & 2,122 \\
Non-Workforce Percentage & & & $\mathbf{2 0 . 7 7 \%}$ \\
\hline \multicolumn{1}{c}{ Total Population } & $\mathbf{5 , 0 0 7}$ & $\mathbf{5 , 2 0 9}$ & $\mathbf{1 0 , 2 1 6}$ \\
\hline
\end{tabular}

Source: Ministry of Home Affairs, 2014

More than a quarter of the villagers in Gadingsari (around 26\%) are workers in the agricultural sector. They work as farmers who own the land, cultivators, and farm laborers. Meanwhile, from the data, it can also be seen that the number of workers in the agricultural sector between men and women is almost the same, namely 1,320 men and 1323 women. It means that employment opportunities in agriculture are open to both women and men.

In term of land-use in Gadingsari Village, the utilization is large enough for agricultural rice fields as land use by residents. Land use is a source of information that describes land use distribution in Gadingsari Village, which is used to meet its residents' livelihood needs. Details can be seen in the table below:

Table 2. Land Use in Gadingsari Village

\begin{tabular}{rlrrr}
\hline No. & & Land Use & Area (Ha) & Percentage (\%) \\
\hline 1 & Settlement & 347.58 & 42.82 \\
2 & Rice Field & 294.48 & 36.28 \\
3 & Fishpond & 2 & 0.25 \\
4 & Public Road & 163 & 20.08 \\
5 & Tomb & 3.2 & 0.39 \\
6 & Etc & & 1.48 & 0.18 \\
\hline & & 811.74 & 100 \\
\hline
\end{tabular}

Source: Data of Gadingsari Village Government, 2014

Based on Table 2 above, it can be obtained that the largest percentage of land is used for settlements of $42.82 \%$, then rice fields of $36.09 \%$, ponds of $0.25 \%$, roads of $20.08 \%$, tombs of $0.39 \%$, and others $0.18 \%$. In Gadingsari village, the agriculture-based economy has generally shifted to the service and trade sectors due to the massive conversion of agricultural land to the non-agricultural sector. This shift began when the rapid Alsintan were used in the last 2 decades. The pattern of change is seen in female farm laborers who previously worked on on-farm agriculture, then shifted to off-farm. Most of them work as post-harvest laborers, such as peeling onions and peanuts. However, until now, the economy in Gadingsari Village is still dominated by the agricultural sector. The large number of Gadingsari villagers who work in the agricultural sector is one of the village economic system's characteristics experiencing rapid changes. An economy that is experiencing development has a production structure consisting of labor and foodstuffs. The majority of Gadingsari village residents work as farmers or agricultural laborers. Only a few works in government agencies, some work in factories, and generally only young teenagers.

For more than 2 decades, it is increasingly difficult for women in Gadingsari Village to get roles in cultivating agricultural land. Women usually do everything from planting until the harvest season arrives, such as nurseries, planting, fertilizing, weeding, to harvesting. However, along with the development of agricultural mechanization in Indonesia during the old order, which was marked using 
agricultural tools and machinery from the Netherlands in Sekon and the implementation of agricultural mechanization policies that were massively adopted during the New Order era in the 1990s until now (Handaka and Prabowo 2016), it has become a penetration for women laborers. This policy promotes the development of Alsintan, which affect women's situation as agricultural workers and are now being replaced by these tools. Those who are still working as agricultural laborers are only women whose age is far above the productive age or the elderly. Meanwhile, women who are still in the productive age group or adolescents prefer to work in factories far from the village.

\section{Application of Agricultural Equipment and Machinery (Alsintan) in Rural Areas}

Agricultural business is one of the sectors that the government continues to develop, intending to increase production for residents' consumption, and the benefit of all efforts is to increase production (Tri 2018). So, the use of paddy fields must be technically irrigated by mechanization in an agricultural system that will support the harvest quality. Because the reality is that the peasants own very narrow agricultural land, so whatever is produced on that agricultural land is almost impossible to meet the farmers' needs. In Gadingsari Village, as one of the villages where most of the population works as farmers and farm laborers, farmers have implemented mechanization in the agricultural system in the fields.

The state or general description of all modern agriculture is the emphasis on one crop. It uses capital intensification and generally produces labor-saving technology, paying attention to scale economics, namely costly, to get certain benefits. Modern agriculture practically does not differ in concept or operation from large industrial enterprises. This modern agricultural system is now known as agribusiness. For almost all traditional societies, agriculture is not just an economic activity; it is part of their way of life.

Agricultural mechanization is an effort to face the challenges of the complexities of various agricultural problems. Initially, agriculture only relied on natural conditions without making innovations to increase productivity. However, in line with the decline in agricultural land's ability to meet the needs due to the agricultural land conversion, the increasing number of populations causes the increasing need for food. Therefore, humans began to think of effective formulas to increase agricultural productivity.

The reality in the field shows that the use of technology and superior seeds can positively impact some farmers who can reach these technologies and superior seeds (Mulyono 2016). However, on the other hand, the existence of technology and superior seeds harms farmworkers' lives, especially women whose livelihoods depend on other parties who need their services. Nevertheless, with this technology, the livelihoods of farmworkers can be threatened. For example, in managing one ha of land, it takes a few days for 14 laborers to do, but a tractor needs only one person, and it takes less than one day. Thus, the application of agricultural technology, on the one hand, benefits farmers, on the other hand, it can reduce available employment opportunities and ultimately lead to social disparities between the rich and the poor.

\section{Agricultural Mechanization: Marginalizing Women Agricultural Workers}

Agricultural development in Gadingsari village has caused mechanization symptoms and various socio-economic changes in the community. The occurrence of changes in a relationship pattern between men and women in the mastery of technology in agriculture has become a perpetual polemic. Ironically, this situation also gives rise to symptoms of discrimination in the "division of labor" between men and women farm laborers. It is empirically evident in the situation of women agricultural laborers. This condition can be interpreted as a problem and obstacle in the development process because it is feared that it can marginalize and even eliminate the role of women in productivity, or marginalize women's role (Satyavathi, Bharadwaj, and Brahmanand 2011).

The impact is the marginalization of women farmers and farm workers, in which women are always left behind compared to men. In agricultural development planning in the past, it was impossible to ignore these women farmers (Elizabeth 2016). This problem causes the position of women to be increasingly limited in agricultural economic activities. Internally, women's limitations are reflected in their lower education, skills, confidence in their abilities, and self-potential. Externally, this limitation is reflected in the lower access of women to various opportunities outside their household. 
In their research in Central Java in the 1980s, White and Hastuti saw that the relationship between men and women in an agriculture community reflected a "different but equal" position. Men and women played a role in mutual interests and complement each other. The separation of roles and influences between genders was complementary to achieve common goals, namely welfare in households and communities. Although this "different but equal" position was recognized in various development programs, their implementation was not. The most benefactors of agriculture development were men. Therefore, a "different and unequal" position real but hidden oppression of women was the reality (Hastuti 2004).

Various limitations that reflect women's marginalization can be seen in accessing education, employment, and business opportunities. Besides technological innovation, discrimination appears in wage levels, types, and values of work (working at the lowest level), jobs segregated by gender, limited access of women workers or entrepreneurs compared to men. Women in the context of their social status as workers are often judged to "forget their nature" that women should only take care of the household and even find it difficult to determine and make decisions in various dimensions. In fact, in the current era of globalization, economic competitiveness is increasingly complex, difficulties in getting a job are increasingly limited, high competition for job and business opportunities and family forms are getting smaller.

Gender bias in agriculture in Gadingsari Village cannot be separated from the classical perspective to see unbalanced and discriminatory women farmers with obligations that confine and trap them in it. The classic nuance of women peasants' oppression amid the harshness of life in the agricultural sector is a gender dimension issue (Fischer et al., 2018). Besides that, the dual roles they play also reflect women's oppression; apart from being housewives (domestic sector), they are also required to earn a living (public sector) to reduce the burden on their economy and household life. Values and customs play a vital role in discussing the role, especially women farmers' opportunities, and potential in the agricultural sector. The penetration of new technologies (superior seeds, hullers/thresher, mechanization of land processing, and herbicides) has reduced and displaced the job opportunities of women agricultural laborers in Gadingsari Village.

\section{The Heavy Burden of Women Farm Workers}

It is not uncommon to see a woman in Gadingsari Village return from the fields on foot while carrying agricultural produce on her back with her body slightly bent under the weight. When she arrives home, she has to immediately work on her daily routine: cooking, washing, taking care of children, and many other domestic tasks. This fact has been integrated into women farmworkers' lives in Gadingsari Village and has almost become a play that cannot be avoided. As part of the daily work, the women farmworker appears as a figure with loads of burdens. On the one hand, they must carry out their innate nature as an ordinary being: giving birth to and becoming mothers for children, and on the other hand, they must carry out their profession of cultivating other people's land (Kurniawan 2015).

The lives of women farmworkers often go unnoticed in development and often create paradoxes. Agricultural development that is less inclusive for women farmworkers has made it more difficult to earn a living in this sector. The results of their hard work, which is often not worth the effort, keep them in poverty. Consequently, there is a kind of rebellion from within the women farmworkers. Some of them want to escape the burden of poverty by looking for other jobs. An example that is easy to find is the proliferation of women workers abroad. Meanwhile, those who have failed to work abroad are forced to remain farm laborers with physical and psychological burdens.

Farm labor is a profession where someone manages other people's land with wages according to the employer's agreement. The farm labor profession with a bad connotation is synonymous with destitution (poverty) and fatigue. It is clear here that women farmworkers need serious attention from various parties, especially the government and private institutions, which often carry out programs and ideas in the name of women's empowerment. In the meantime, what women farmworkers face is the lack of assets and opportunities to develop themselves. They can only surrender to conditions that increasingly do not support the continuity of gender-friendly agricultural economic activities. Another concern is the existence of men (husbands) who seem to have not yet thoroughly carried out their responsibilities as main breadwinners. The husband's income cannot meet his household's needs, so there are still many women who still accept burdens beyond their responsibilities. In fact, in making a living, women are often the backbone of the family.

Sodality: Jurnal Sosiologi Pedesaan | Vol. 9 (02) 2021 
Inequality in the mastery of this tool is not only due to the presence of men. The emergence of agricultural modernization changes the land management mechanism, which requires contemporary technology. The technology created is not gender-friendly, so the mastery of this technology is also dominated by men. The stigma that develops in society is it is men who are more vital work with agricultural tools than women. It becomes a new problem, and it turns out that there are still grim faces of women farmworkers, faces oppressed by fate (Kurniawan 2020).

\section{Agriculture Mechanization as a Risk for Women Farm Workers}

The risk society is a term that indicates that there is a change to new conditions in human life today (Beck 1992). There are differences of opinion on this matter. The change referred to is leading from the era of modernity to advanced modernity. At the same time, some also say that the change occurs from modernity to the postmodern era. Even so, both thoughts agree that these changes have significant consequences. The consequence is the demand for awareness that human life is now filled with uncertainties and risks that can threaten at any time. Thus, an essential characteristic of risk society is that risk, and the means to overcome or minimize efforts, becomes a central problem of human life.

Ulrich Beck emphasizes that various changes have accompanied the shift from a "classic" stage of modernity to "new" modernity marked by the emergence of a risk society, one of the changes referred to in terms of central problems. In "classical" modernity, the central problem revolves around wealth and how to distribute it evenly. Meanwhile, in the "new" modernity, the central problem is risk and how to prevent, minimize, or channel it (Beck 1992).

Change is considered a natural thing in society; it generally takes place as the development of life. Of course, the direction and goals of this development are expected to produce everything positive. However, it would be hard to think if changes could cause concern, even if these effects could last a long time. If humans believe the negative impact is also standard, then they believe that they will experience a crisis. Then, they will end up in a disaster that they believe in or create by themselves.

From the change process directed at the mechanization of agriculture in Gadingsari Village, new technology in land management was born, which often shifted values from the old ones. New technology has overhauled the old agricultural structure, notably eliminating many women workers in the agricultural sector. Women workers lose the opportunity to take part in the agricultural production process through traditional methods, for example, derep (replaced by tebasan) and nutu (pounding rice) replaced by rice grinding machines (Abdullah 1997).

Societies are often trapped in situations of risk and pressure to demand reflection to come out of these situations. People who act according to the times without prioritizing reflection patterns and understanding the risks that occur will be further marginalized because of the crisis in their knowledge. For example, female agricultural laborers in Gadingsari Village will be affected by the crisis due to the agricultural mechanization process that occurs. Responding to these risks, women farmworkers who do not have a survival strategy and lead an uncertain lifestyle can be said to be experiencing an intellectual crisis. On the other hand, women farmworkers who can explore themselves and have strategies to find alternative sources of income are among the subjects who can reflect on the risks they face.

Although mechanization generates risk first, it will also provide a possible reflection of the risks it creates. From the findings in the field, women agricultural laborers in Gadingsari Village who were the subject of agricultural mechanization risk began to reflect these risks. Then they began to observe and thought about the risks and consequences. Therefore, they carried out strategies to survive within limitations so that they could still meet the economic needs of their families. Therefore, reflexivity in thoughts, attitudes, or actions will play a role in anticipating or reducing the impact or consequence of the risk of agricultural mechanization (Kurniawan 2015).

Some women farmworkers in Gadingsari Village were sensitive and responsive to various opportunities to increase (even the main one) income to help the household economy. With the increase in income obtained through a double role of female farm laborers, the daily household food needs could be fulfilled. Regarding these conditions, women farmworkers carried out the family economic fulfillment strategy by looking for alternative jobs through landowners after harvesting. Women farmworkers offered services such as picking shallots, beans, lifting rice. Often the wages 
they received were in the form of agricultural products, such as rice or shallots. The wages they earned were used as a food source for the family, which used up consumption (Kurniawan 2018b). This condition is far from the expectation of food security, which is the fulfillment of food for a household, which indicates the adequacy of food that is good, safe, evenly distributed in quantity and quality (Kurniawan 2018a).

\section{The Principle of Safety First as Risk Reflexivity}

Women farmworkers in Gadingsari Village have characteristics that are in line with the conditions experienced by most farmworkers who live in conditions of vulnerability and poverty. Women farmworkers in Gadingsari Village face decreasing employment opportunities in agriculture because they have been replaced by the massive development of agricultural tools and machinery. It dramatically affects the economic instability and income to meet family needs. In this condition, women farmworkers must think thoroughly and hard about how they can survive with these existing conditions. Even though women farmworkers must do various things to stay alive, they still work in agriculture because this is the only sector they can do.

From women farmworkers' statements, it can be explained that the most visible thing before and after agricultural mechanization is their decreased income. Initially, at every harvest time, women farmworkers earn a high income, but for the current conditions, women farmworkers often only achieve half of the payment or less. This condition occurs because of the control of the agricultural equipment in the hands of men. To react to such conditions women agricultural workers will choose to minimize their expenses by reducing consumption. By reducing meal portion or changing to lower price or quality of food. This method is one of the options for female farm laborers to overcome the risks that exist. Later, women farmworkers will face new problems, namely the higher expenditures spent on basic household needs and the decreasing income earned as agricultural laborers.

As did the farmers in Scott's era, they would do the same thing, namely the principle of safety first, which prefers to minimize income rather than maximize revenue with greater risk. Female farmworkers carry out this condition because they think that even with minimal yields, the most important thing for female farmworkers is that they can still manage family finances for future meals (Scott 1977). Reflected by what the informants have done, it turns out that several other women farmworkers have done the same thing. Women farmworkers in Gadingsari village are willing to work extra partially to support household needs. For example, they sell small items, look for grass to feed livestock, some have their livestock, or become casual laborers to earn income.

It can be implied that a woman farmworker, especially in Gadingsari Village, will do various ways to minimize the risks they are likely to face. This condition concurs with the principle of safety first put forward by Scott. A farmer would prefer to minimize the possibility of a disaster than maximize his average income (Scott 1977). This strategy overrides the options that exist, even though they give the expectation of a higher average net yield, they carry out significant risks of loss that could jeopardize its subsistence. With the principle of avoiding this risk, many economists who study low-income agriculture in the third world have noted: for farmers who live within subsistence limits, risk aversion can be extreme (Behrman 1978). There is a tendency to give exceptional value to maintain survival and position instead of changes and improvements (Mellor 2017).

This risk-averse attitude is also advocated to explain why farmers in Scott's day preferred to grow subsistence crops over non-food crops for sale. Meanwhile, the philosophy of avoiding risks in women agricultural laborers is carried out by changing the type of staple food or reducing the portion of food. Women farmworkers do this to minimize the risks they will face even with minimal income.

\section{CONCLUSION}

Agricultural mechanization is part of an era development process that is not usually negated to increase agricultural production quality and quantity. However, the application of agricultural mechanization in terms of changes in the technology of agricultural tools and machinery (alsintan) can eliminate farmworkers' livelihoods, mostly women agricultural laborers whose role is replaced by machinery. Their welfare can be threatened if there is no follow-up by the policymakers to pay attention to the farmworkers' fate. 
In rural communities such as in Gadingsari Village, the majority of which are from middle to lowerincome families, a woman often plays a role not only as a wife or a mother but also as a worker and her family's backbone. Women farmworkers also have a role to play in helping their husbands prosper and maintain their families' economic stability. Even though the position of women is essential, women farmworkers still face various problems and obstacles. Internally, there are various obstacles to advance women's roles due to the relatively low levels of education, skills, motivation, and selfconfidence. Externally, various social supports from society, cultural values, appropriate technology, and policies are still not pro-women.

Increasing the productivity of the women farmworkers has a strategic role and potential in supporting the increase and acquisition of farm household income in rural areas. Various problems and constraints, both internally and externally, need to be overcome in various ways. These can be done through the protection of female workers by increasing the effectiveness of counseling and training, and improving wage regulations, facilities, and work opportunities that are gender balanced. The development of women agricultural laborers also needs to be improved and empowered as a receiving system to accelerate technology absorption by women farmers. These opportunities can become incentives and take sides for women farmworkers. This article can be used as feedback for planners, compilers, and policymakers.

\section{ACKNOWLEDGMENT}

Thanks to Dewi Cahyani Puspitasari, Lecturer at the Department of Sociology, Gadjah Mada University, for her technical assistance and substance input in this research.

\section{REFERENCES}

Abdullah, Irwan. 1997. Sangkan paran gender. Pustaka Pelajar.

Akter, Sonia, Pieter Rutsaert, Joyce Luis, Nyo Me Htwe, Su Su San, Budi Raharjo, and Arlyna Pustika. 2017. "Women's Empowerment and Gender Equity in Agriculture: A Different Perspective from Southeast Asia." Food Policy 69:270-79. doi: 10.1016/j.foodpol.2017.05.003.

Beck, Professor Ulrich. 1992. Risk Society: Towards a New Modernity. SAGE.

Behrman, Jere R. 1978. Development, the International Economic Order, and Commodity Agreements. Addison-Wesley Publishing Company.

Boserup, Ester. 1984. Peranan Perempuan Dalam Perkembangan Ekonomi. Yayasan Obor Indonesia.

Cele, Lungelo, Ingeborg Adelfang Hodgson, Michael Boateng, and Eugene Moses. 2020. "Empowering Women through Mechanisation: Where Are the Opportunities?" Retrieved October 21, 2020 (https://www.rural21.com/english/news/detail/article/empowering-womenthrough-mechanisation-where-are-the-opportunities.html).

Creswell, John W. 2013. Qualitative Inquiry and Research Design: Choosing Among Five Approaches. SAGE.

Elizabeth, Roosganda. 2016. "Pemberdayaan Wanita Mendukung Strategi Gender Mainstreaming dalam Kebijakan Pembangunan Pertanian di Perdesaan." Forum penelitian Agro Ekonomi 25(2):126-35. doi: 10.21082/fae.v25n2.2007.126-135.

FAO. 2011. "The Role of Women in Agriculture.” ESA Working Paper No 11-02 48.

Fischer, Gundula, Simon Wittich, Gabriel Malima, Gregory Sikumba, Ben Lukuyu, David Ngunga, and Jacqueline Rugalabam. 2018. "Gender and Mechanization: Exploring the Sustainability of Mechanized Forage Chopping in Tanzania." Journal of Rural Studies 64:112-22. doi: 10.1016/j.jrurstud.2018.09.012. 
Geertz, Clifford. 1983. Involusi pertanian: proses perubahan ekologi di Indonesia. Bhratara Karya Aksara.

Handaka, nFN, and Abi Prabowo. 2016. "Kebijakan Antisipatif Pengembangan Mekanisasi Pertanian." Analisis Kebijakan Pertanian 11(1):27-44. doi: 10.21082/akp.v11n1.2013.27-44.

Hastuti, Endang Lestari. 2004. "Pemberdayaan Petani dan Kelembagaan Agribisnis Lokal dalam Perspektif Gender :" ICASERD Working Paper No.40 24.

Johnson, Nancy L., Chiara Kovarik, Ruth Meinzen-Dick, Jemimah Njuki, and Agnes Quisumbing. 2016. "Gender, Assets, and Agricultural Development: Lessons from Eight Projects." World Development 83:295-311. doi: 10.1016/j.worlddev.2016.01.009.

Kansanga, M., P. Andersen, D. Kpienbaareh, S. Mason-Renton, K. Atuoye, Y. Sano, R. Antabe, and I. Luginaah. 2019. "Traditional Agriculture in Transition: Examining the Impacts of Agricultural Modernization on Smallholder Farming in Ghana under the New Green Revolution." International Journal of Sustainable Development \& World Ecology 26(1):11-24. doi: 10.1080/13504509.2018.1491429.

Kawarazuka, Nozomi. 2018. "Agricultural Mechanization: How Far Do Women Farmers Benefit?" CGIAR Research Program on Roots, Tubers and Bananas. Retrieved October 21, 2020 (https://www.rtb.cgiar.org/news/agricultural-mechanization-far-women-farmers-benefit/).

Kodiran, and Bambang Hudayana. 1990. Peranan wanita dalam sawah surjan. Pusat Penelitian Kependudukan, Universitas Gadjah Mada.

Kurniawan, Fuat Edi. 2015. "Mekanisasi Pertanian Dan Strategi Buruh Tani Perempuan Dalam Memenuhi Perekonomian Keluarga." Universitas Gadjah Mada.

Kurniawan, Fuat Edi. 2018a. "Food Sovereignty and The Paradox of Agricultural Development." Journal of Indonesian Social Sciences and Humanities 8(1):85-88. doi: 10.14203/jissh.v8i1.132.

Kurniawan, Fuat Edi. 2018b. Kedaulatan Pangan Dan Paradoks Pembangunan Pertanian. yf9xg. Center for Open Science.

Kurniawan, Fuat Edi. 2020. "Mekanisasi Pertanian Dan Nasib Buruh Tani Perempuan." OSF Preprints.

Mahanani, Subekti. 2003. "Keadilan Agraria Bagi Perempuan Tani.” Jurnal Analisis Sosial 8(2).

Manning, Chris. 2000. "Labour Market Adjustment to Indonesia's Economic Crisis: Context, Trends and Implications." Bulletin of Indonesian Economic Studies 36(1):105-36. doi: 10.1080/00074910012331337803.

Mehta, C., Laxman Gite, and Abhijit Khadatkar. 2018. "Women Empowerment through Agricultural Mechanization in India." Current Science 114. doi: 10.18520/cs/v114/i09/1934-1940.

Mellor, John W. 2017. Agricultural Development and Economic Transformation: Promoting Growth with Poverty Reduction. Springer.

Mulyono, Mulyono. 2016. "Primary Data: Direct Interview."

Priminingtyas, Dina Novia. 2013. "Marginalisasi Perempuan Dalam Pembangunan Pertanian." 6.

Research Institute (IFPRI), International Food Policy. 2019. Gender and Agricultural Mechanization: A Mixed-Methods Exploration of the Impacts of Multi-Crop Reaper-Harvester Service Provision in Bangladesh. 0 ed. Washington, DC: International Food Policy Research Institute.

Rola-Rubzen, Maria Fay, Thelma Paris, Jacob Hawkins, and Bibek Sapkota. 2020. "Improving Gender Participation in Agricultural Technology Adoption in Asia: From Rhetoric to Practical Action." Applied Economic Perspectives and Policy 42(1):113-25. doi: 10.1002/aepp.13011.

Sajogyo. 1973. Modernization Without Development in Rural Java. 
Satyavathi, C. Tara, Ch. Bharadwaj, and P. S. Brahmanand. 2011. "Role of Farm Women in Agriculture: Lessons Learned." Gender, Technology and Development 14(3):441-49. doi: 10.1177/097185241001400308.

Scott, James C. 1977. The Moral Economy of the Peasant: Rebellion and Subsistence in Southeast Asia. Yale University Press.

Sims, Brian, and Josef Kienzle. 2017. "Sustainable Agricultural Mechanization for Smallholders: What Is It and How Can We Implement It?" Agriculture 7(6):50. doi: 10.3390/agriculture7060050.

Suratiyah, Ken, Sunarru Samsi Hariadi, I. Ketut Sudibia, and I. Wayan Sudarta. 1991. Pembangunan pertanian dan peranan wanita di pedesaan Yogyakarta dan Bali. Pusat Penelitian Kependudukan, Universitas Gadjah Mada.

Tri, Sudaryono. 2018. "The Impact of Agricultural Machinery Equipment on Rice Farming in East Java in Effort to Scarcity of The Labor." Eurasia: Economics \& Business 7(1).

Yin, Robert K. 2009. Case Study Research: Design and Methods. SAGE. 